\title{
PENERAPAN MODEL BRAIN BASED LEARNING DALAM PEMBELAJARAN DI SMAN 10 BANDUNG
}

\author{
${ }^{1}$ Hana Silvana, dan ${ }^{2}$ Adhitya Wibisono \\ ${ }^{1}$ Departemen Kurikulum dan Teknologi Pendidikan Universitas Pendidikan Indonesia \\ e-mail: ${ }^{1}$ rainasilva10@gmail.com
}

\begin{abstract}
Abstrak. Penelitian ini berjudul "Penerapan Model Brain Based Learning Dalam Pembelajaran di SMANegeri 10 Bandung." dilatarbelakangi oleh adanya permasalahan di lapangan mengenai kesenjangan hasil belajar siswa SMA yang memperlihatkan kurangnya kemampuan siswa dalam memahami materi pelajaran. Model brain based learning merupakan suatu model khusus untuk menilai potensi yang sesungguhnya dari otak dalam proses pembelajaran sehingga berdampak adanya peningkatan dalam hasil belajar siswa. Penelitian ini bertujuan untuk mengetahui perbedaan hasil belajar mata pelajaran geografi antara siswa yang diberi model brain based learning dengan siswa yang diberi model konvensional yang dilihat dari ranah kognitif,afektif dan psikomotor. Metode yang digunakan dalam penelitian ini yaitu Quasi Experiment dengan tipe Non-Equivalen Control Group Design. Sampel dalam penelitian ini yaitu siswa kelas XI IPS di SMA Negeri 10 Kota Bandung yang diambil dengan menggunakan teknik cluster random sampling. Pengumpulan data yang dilakukan yaitu menggunakan tes prestasi belajar dengan soal pilihan ganda dan format observasi. Metode penelitian ini dengan cara membagi siswa kedalam kelas kontrol dan kelas eksperimen sebelum diberikan perlakuan/treatment setiap kelas terlebih dahulu diberikan pretes lalu pemberian perlakuan/treatment dan pada tahap akhir diberikan postes untuk mengetahui perbedaan masing-masing kelas. Berdasarkan hasil penelitian didapatkan hasil bahwa terdapat perbedaan hasil belajar geografi antara siswa yang diberi model brain based learning dengan siswa yang diberi model konvensional pada mata pelajaran geografi kelas XI. Dari analisis data yaitu rekapitulasi peningkatan skor hasil belajar kognitif dengan gain ternormalisasi $\langle g\rangle$ sebesar 0,62 dengan kategori sedang. Untuk hasil belajar ranah afektif siswa didapatkan dengan rata-rata nilai pada kategori rendah dan hasil belajar ranah psikomotor dengan rata-rata nilai pada kategori sedang.
\end{abstract}

Kata kunci : Brain Based Learning,Hasil Belajar Siswa, pembelajaran

\section{Pendahuluan}

Pendidikan merupakan salah satu aspek yang sangat penting dalam kehidupan manusia. Namun, kualitas pendidikan di Indonesia sampai saat ini masih belum optimal. Pendidikan merupakan kegiatan mengoptimalkan perkembangan potensi, kecakapan, dan karakteristik pribadi siswa. Kegiatan pendidikan diarahkan kepada pencapaian tujuan tujuan tertentu yang disebut tujuan pendidikan. Tujuan pendidikan tersebut tentunya mengarah pada keberhasilan dalam dunia pendidikan.Keberhasilan dalam dunia pendidikan tidaklah lepas dari proses belajar mengajar dan keandalan model yang digunakan. Keberhasilan belajar siswa pada umumnya dan siswa SMA khususnya masih diukur dari seberapa jauh siswa menguasai konsep yang diajarkan. Akan lebih baik jika kefektifan model pembelajaran tidak hanya ditinjau dari penguasaan konsep saja, tetapi perlu dianalisis apakah konsep yang diajarkan dapat lekat dalam ingatan siswa atau cepat terlupakan. Konsep yang dipahami secara baik oleh siswa dapat lekat dan disimpan dalam ingatan yang kemudian akan dipergunakan pada saat diperlukan. 
Upaya meningkatkan pendidikan menjadi tugas dan tanggung jawab guru, karena gurulah yang langsung membina para siswa di sekolah melalui kegiatan belajar mengajar. Namun upaya meningkatkan kualitas pendidikan bukanlah hal yang mudah, karena itu diperlukan guru yang professional guna meningkatkan mutu pendidikan dan tujuan pendidikan nasional dapat terwujud. Seorang guru yang baik harus mampu menyusun suatu strategi pembelajaran yang mampu membawa peran serta siswa secara aktif belajar dikarenakan kesadaran dan ketertarikan siswa yang cukup tinggi, bukan semata-mata untuk memenuhi kewajiban. Guru dituntut dapat menyajikan kegiatan belajar mengajar yang mampu membangkitkan motivasi belajar siswa. Motivasi belajar merupakan motor penggerak yang menjadikan siswa secara aktif melibatkan diri untuk belajar. Usaha guru untuk membangkitkan motivasi belajar pada siswa diarahkan pada unsur internal (siswa) dan unsur eksternal (diluar siswa). Contoh dari unsur eksternal tersebut adalah suasana kelas yang efektif untuk belajar. Untuk mewujudkan tujuan ini sangat diperlukan peran guru secara aktif sebab guru sebagai pengelola proses pembelajaran bertindak selaku fasilitator hendaknya berusaha menciptakan kondisi pembelajaran yang kondusif, mengembangkan bahan pengajaran dan meningkatkan kemampuan siswa untuk menyimak dan menguasai tujuan pendidikan yang harus mereka capai, oleh karena itu guru dituntut mampu mengelola proses pembelajaran yang dapat memberikan rangsangan kepada siswa sebagai subyek utama belajar.

Pembelajaran Ilmu Pengetahuan Sosial memiliki fungsi yang fundamental dalam menimbulkan serta mengembangkan kemampuan berpikir kritis, kreatif dan inovatif. Agar tujuan tersebut dapat tercapai, maka Ilmu Pengetahuan Sosial perlu diajarkan dengan cara yang tepat dan dapat melibatkan siswa secara aktif yaitu melalui proses dan sikap ilmiah. Mutu pembelajaran Ilmu Pengetahuan Sosial perlu ditingkatkan secara berkelanjutan untuk mengimbangi perkembangan ilmu dan teknologi. Untuk meningkatkan mutu pembelajaran tersebut, tentu banyak tantangan yang dihadapi. Sementara ini masih banyak orang beranggapan bahwa Ilmu Pengetahuan Sosial merupakan pelajaran yang sulit karena dituntut adanya kemampuan menghafal yang tinggi terhadap materi pelajaran, serta kurang menarik minat di kalangan siswa. Permasalahan yang dihadapi siswa di SMA adalah "hasil belajar ilmu pengetahuan sosial khususnya geografi secara nasional belum mencapai angka minimal daya serap 68\% yang telah ditentukan" (Kamdi, 2009:34). Salah satu faktor dalam pembelajaran Ilmu Pengetahuan Sosial guru lebih banyak berceramah, sehingga siswa menjadi cepat bosan dan menyebabkan hasil belajarnya rendah. Hal itu ditambah dengan pendapat siswa bahwa pelajaran Ilmu Pengetahuan Sosial dianggap sulit, sehingga tidak menarik untuk belajar, berdampak pada rendahnya hasil belajar yang diperoleh siswa.

Proses pembelajaran melalui interaksi guru-siswa, siswa-siswa, dan siswa-guru, secara tidak langsung menyangkut berbagai komponen lain yang saling terkait menjadi suatu sistem yang utuh. Pendidikan dapat mengalami perubahan ke arah yang lebih baik bahkan sempurna sehingga sangat diharapkan adanya pembaharuan-pembaharuan. Salah satu upaya pembaharuan dalam bidang pendidikan adalah pembaharuan model atau meningkatkan relevansi model mengajar. Model mengajar dikatakan relevan jika mampu mengantarkan siswa mencapai tujuan pendidikan pada umumnya. Salah satu model pembelajaran untuk mengantisipasi kelemahan model ceramah adalah model Brain Based Learning, yaitu suatu proses belajar mengajar dimana siswa aktif untuk membangun pengetahuannya yang dilandasi oleh struktur kognitif yang telah dimilikinya serta didasarkan pada cara otak bekerja sehingga diharapkan pembelajaran dapat diserap oleh otak lebih optimal. Implikasi model Brain Based Learning yaitu 
Persiapan, Akuisisi, Elaborasi, Formasi Memori, dan Integrasi Fungsional. Inti dari Model Brain Based Learning adalah siswa berperan aktif membangun pengetahuan yang dimilikinya, guru berperan fasilitator dan mediator pembelajaran.

Desain penelitian yang digunakan adalah kuasi eksperimen. Penelitian kuasi eksperimen menggunakan seluruh subjek dalam kelompok belajar (intact group) untuk diberi perlakuan (treatment). Penelitian ini bertujuan untuk mengetahui ada tidaknya perbedaan hasil belajar geografi kelas XI yang diajarkan dengan menggunakan model Brain Based Learning dan model konvensional di SMAN 10 Bandung, sehingga subjek penelitian dikelompokkan menjadi dua kelompok yaitu kelompok eksperimen dan kelompok kontrol. Kelompok eksperimen yaitu kelompok siswa yang diberikan perlakuan dengan model Brain Based Learning, dan kelompok kontrol adalah kelompok siswa yang diberikan perlakuan dengan menggunakan model konvensional. Peneliti menggunakan model Quasi Experimental Design dengan tipe Non-Equivalen Control Group Design. Dalam desain penelitian ini dibedakan dengan adanya pretest sebelum perlakuan diberikan, hal tersebut dapat digunakan untuk melihat pengaruh perlakuan terhadap pencapaian skor (gain score). Berdasarkan metode kuasi eksperimen yang ciri utamanya adalah tanpa penugasan random dan menggunakan kelompok yang sudah ada (intact Group), maka peneliti menggunakan kelompok yang sudah ada sebagai sampel, jadi peneliti mengambil sampel dari anggota populasi dalam bentuk kelas. Alasannya apabila pengambilan sampel secara individu dikhawatirkan situasi kelompok sampel menjadi tidak alami. Berdasarkan pendapat tersebut, maka peneliti memilih dua kelas yang yang dijadikan kelas kontrol dan eksperimen yaitu kelas XI IPS 1 dan XI IPS 5. Dalam penelitian ini, instrumen yang digunakan oleh peneliti yaitu menggunakan pedoman observasi dan Pedoman tes yang berupa soal-soal tes tertulis. Pada penelitian ini model tes digunakan untuk mengumpulkan data mengenai hasil belajar geografi setelah mendapat perlakuan dengan model pembelajaran dengan pendekatan Brain Based Learning untuk kelas eksperimen dan pendekatan konvensional untuk kelas kontrol. Metode observasi digunakan dalam melakukan penilaian afektif dan penilaian psikomotor.

\section{Hasil Penelitian dan Pembahasan}

Pembelajaran berbasis otak merupakan sebuah cara berpikir tentang proses pembelajaran. Pendekatan ini adalah pembelajaran yang diselaraskan dengan cara otak yang didesain secara alamiah untuk belajar. Ketika belahan otak kanan dan otak kiri digunakan, maka kekuatan dan fungsi-fungsi otak manusia maksimal. Bahkan bekerjanya pun maksimal. Dampak positif yang bisa dirasakan ialah kecerdasan seseorang atau seorang anak akan semakin meningkat. Fungsi otak tersebut tidak hanya bekerja sendiri-sendiri tetapi saling mempengaruhi satu sama lain. Menurut Mudyaharjo dalam Masykur (2009:122) "pendidikan yang berbasis pada otak adalah sistem yang mengakomodasikan pengalaman-pengalaman atau kegiatan belajar yang diminati oleh setiap siswa. Sedangkan metodenya adalah lebih berupa penyediaan lingkungan dan fasilitas yang memungkinkan berlangsungnya proses belajar secara bebas pada setiap anak untuk mengembangkan bakat dan minatnya masing-masing". Terkait dengan perkembangan pembelajaran yang berhubungan dengan cara kerja otak dan mengembangkan kedua belahan otak, maka guru perlu menggunakan strategi pembelajaran yang terkait dengan emosional, sosial, kognitif, fisik dan reflektif. Sapa'at (2009:76) juga mengungkapkan bahwa, "Brain Based Learning menawarkan sebuah 
konsep untuk menciptakan pembelajaran yang berorientasi pada upaya pemberdayaan potensi otak siswa".

Hasil penelitian menunjukan pada ranah kognitif ini aspek yang diuji yaitu aspek C4/analisis dimana aspek ini mengukur sejauh mana tingkat kemampuan analisis siswa dalam pelajaran geografi ini. Hasil pada penelitian ini menunjukan bahwa terdapat perbedaan siswa yang menggunakan model brain based learning dengan siswa yang menggunakan model konvensional. Namun bukan berarti kelas kontrol tidak terdapat peningkatan nilai pada postest, kedua kelas baik kontrol dan eksperimen sama-sama memiliki kenaikan nilai pada postest. Hal tersebut dapat dilihat pada nilai tertinggi kelas kontrol dan eksperimen yang hampir sama, namun tidak semua siswa mengalami kenaikan nilai yang sama. Dengan nilai $n$-gain sebesar 0,62 untuk kelas eksperimen dan 0,42 untuk kelas kontrol, walaupun dalam kategori yang sama tetapi n-gain kedua kelas terdapat perbedaan nilai. Hasil belajar pada ranah afektif dan psikomotor diukur dengan menggunakan format observasi berbentuk rating scale. Observer memberikan tanda checklist $(\sqrt{ })$ sesuai dengan kategori yang terlihat pada saat observasi. Skor yang diperoleh siswa pada aspek afektif dan psikomotor dihitung rekapitulasinya dan dijumlahkan pada skor masing-masing untuk setiap kategori. Setelah diketahui nilai presentasenya, maka akan diketahui tingkat keberhasilan hasil belajar. Hasil belajar yang diukur pada penelitian ini yaitu aspek keseriusan dalam pembelajaran (receiving/A1) dan aspek melakukan penyelidikan (set/P2). Hasil belajar ini diukur melalui kriteria tertentu dari lembar observasi. Pada setiap pertemuan, observer menilai melalui format observasi terhadap aktivitas siswa pada saat pembelajaran.

Hasil belajar ranah afektif yaitu A1/serius terhadap pembelajaran untuk kategori 1 siswa yang hanya mendengarkan dan memperhatikan saja dengan nilai rata-rata kelas kontrol sebesar 23,23\%, dan kelas eksperimen yaitu 16,16\%. Kategori 2 yaitu siswa yang mendengarkan, memperhatikan dan mencatat tetapi tidak bertanya mengenai materi pelajaran dengan nilai rata-rata kelas kontrol sebesar 68,70\%, dan kelas eksperimen yaitu 55,56 \%. Kategori 3 yaitu siswa yang mendengarkan, memperhatikan, mencatat dan bertanya mengenai materi pelajaran dengan nilai rata-rata kelas kontrol sebesar 8,08\%, dan untuk kelas eksperimen yaitu 28,28\%.Hasil belajar ranah psikomotor yaitu P2/melakukan penyelidikan untuk kategori 1 siswa yang siswa yang melakukan penyelidikan tetapi tidak sesuai prosedur dengan nilai rata-rata kelas kontrol sebesar $12,21 \%$ dan untuk kelas eksperimen yaitu 6,06\%. Kategori 2 yaitu siswa yang melakukan penyelidikan dengan benar tetapi terdapat tahapan yang tidak sesuai dengan prosedur dengan nilai rata-rata kelas kontrol yaitu sebesar 45,45\% dan kelas eksperimen yaitu 40,09\%. Kategori 3 yaitu siswa melakukan penyelidikan sesuai dengan prosedur dengan nilai rata-rata kelas kontrol sebesar 42,42\% dan kelas eksperimen yaitu 53,03\%.

Model ini pada dasarnya membantu untuk siswa menggunakan kedua otak kiri dan otak kanan secara bersamaan sehingga kedua belah otak memberikan kineja yang maksimal terhadap pembelajaran. Saat proses pembelajaran berlangsung siswa diberikan kebebasan berupa jargon kelompok hal ini memperlihatkan bahwa siswa tersebut merupakan bagian penting dalam proses pembelajaran sehingga mereka mesara nyaman dan memberikan semangat saat belajar. Sebelum proses belajar baik siswa dan guru melakukan pemanasan yaitu senam otak, siswa dan guru mengikuti instruksi dalam sebuah video yang didalamnya berisi gerakan-gerakan senam otak, hal tersebut bertujuan untuk membuat antara koneksi otak kiri dan otak kanan berjalan karena hal itulah yang menjadi tujuan dari model brain based learning. Pemberian hal 
yang nyata dalam pembelajaran merupakan bagian terpenting, dalam hal ini guru memberikan demonstrasi awal berupa penjelasan singkat materi dengan keadaan yang nyata sehingga siswa benar-benar merasa pembelajaran akan semakin menarik untuk dipelajari. Hal ini sesuai dengan teori brain based learning dimana siswa dapat mendorong kinerja otak kanan dan otak kirinya dalam proses pembelajaran, dengan harapan dalam proses pembelajaran siswa tidak merasa jenuh dan materi pembelajaran yang diterima siswa dapat bertahan lama sehingga hasil belajar siswa dapat meningkat. Menurut eric jensen bahwa model brain based learning merupakan pembelajaran yang diselaraskan dengan cara otak yang didesain secara alamiah untuk belajar, hal tersebut membuat penerapan model ini mengajak siswa untuk mengoptimalkan kedua belah otak agar pembelajaran lebih bermakana.

Ketika proses pembelajaran berlangsung siswa bersama guru melakukan pemanasan otak dengan cara senam otak. Hal ini bertujuan agar siswa dapat mengoptimalkan kedua belah dari bagian otak kiri dan kanan, sehingga siswa lebih mudah memahami materi dengan cepat karena kedua belah otak mereka bekerja secara maksimal. Hal tersebut sesuai dengan pernyataan Denison (2002:88) "Senam otak sangat baik dilakukan pada awal pembelajaran, yang berguna membuka titik-titik positif belajar. Setelah belajar, senam otak juga bisa dilakukan kembali untuk bisa membuat santai/rileks akibat proses pembelajaran yang melelahkan/mengangkang/membutuhkan konsentrasi tinggi. senam otak dapat pula berfungsi meredakan dan mengurangi stress". Tahapan pertama tersebut membuat siswa menjadi lebih aktif dan tentu membuat pembelajaran menjadi menarik sehingga secara tidak langsung siswa mengikuti arahan dari guru dan lebih mengikuti pelajaran lebih baik. Pada tahapan model brain based learning memang secara keseluruhan menuntut partisipasi aktif siswa dalam proses pembelajaran.

Peran dari tahapan pembelajaran berguna untuk meningkatkan keaktifan siswa dalam mengikuti rangkaian pelajaran, selain itu mind maping, demonstrasi dan analogi tentang materi yang dilakukan guru mengenai pembelajaran membuat siswa berfikir dan menalar tentang materi tersebut, hal ini membuat secara tidak langsung proses pembelajaran berjalan dengan sendirinya, sehingga siswa lebih fokus dalam memecahkan masalah dan tidak disadari bahwa siswa telah mengoptimalkan kedua belah otak mereka. Pembagian kelompok oleh guru berperan untuk lebih meningkatkan keaktifan siswa didalam kelas, selain itu pembagian kelompok ini bertujuan untuk memfasilitasi siswa agar mampu menyerap informasi dengan baik, serta pemberian reward atau penghargaan kepada siswa merupakan hal yang penting walaupun kinerja mereka belum maksimal. Siswa sebagai pembelajar dirancang untuk dapat membangun pengetahuan mereka sendiri melalui proses belajar aktif. Hal ini sejalan dengan pernyataan sapaat dalam (Astawan 2010:132) "Suatu keberhasilan belajar siswa ditentukan oleh seberapa mampu mereka membangun pengetahuan dan pemahaman tentang suatu materi pelajaran berdasarkan pengalaman belajar yang mereka dapatkan dan mereka alami sendiri".

Selama proses kegiatan praktikum berlangsung di kelas eksperimen siswa mampu mengerjakan perintah dengan baik, siswa tidak lagi cenderung bertanya kepada guru, namun secara tidak langsung mereka terpacu untuk bekerja sama dalam kelompoknya. Setelah kegiatan praktikum tiap-tiap kelompok mempersentasikan hasil praktikumnya didepan kelas sedangkan kelompok lain menanggapinya, dan mereka juga saling menghargai sehingga tidak terjadi keributan didalam kelas. Ranah psikomotor tentu berketerkaitan dengan ranah kognitif dan afektif siswa, hal ini tentu terlihat dari 
hasil belajar kognitif yang baik akan memperlihatkan hasil psikomotor yang baik pula, ketika siswa diminta untuk membuat peta tematik sebaran flora dan fauna di Dunia dan di Indonesia, banyak siswa yang mampu mengerjakan dengan baik walaupun terdapat beberapa kesalahan dalam prosedurnya namun dalam segi hasil cukup memuaskan.

Dengan model brain based learning tentu membuat kondisi/lingkungan pembelajar menjadi menyenangkan, hal ini dikarenakan model ini mengharuskan untuk siswa dan guru bersama-sama menciptakan interaksi yang baik ketika pembelajaran berlangsung, karena sudah seharusnya suatu lingkungan pembelajar dapat menciptakan iklim belajar yang baik dan nyaman dapat membantu siswa dalam memahami materi pelajaran. Hal ini sesuai dengan pernyataan yang diungkapkan oleh Anas Zulkifli (2011:14),"Proses`tersebut harus didukung dengan penciptaan iklim belajar yang humanis, melalui berbagai kegiatan seperti pemeliharaan lingkungan sekolah yang nyaman yang melibatkan siswa secara aktif, melakukan kegiatan-kegiatan yang mirip dengan kehidupan nyata". Sehingga dapat dilihat bahwa ranah psikomotor siswa pada kelas eksperimen yang diberi model brain based learning terjadi peningkatan pada kategori 3 dan penurunan pada kategori 1, hal ini terlihat pada rata-rata persentase kategori 3 yang lebih besar dari kategori 3 untuk kelas kontrol, sehingga siswa terlihat lebih baik dalam mengikuti praktek dan melakukan dengan baik dan benar karena lingkungan belajar yang lebih hidup dibanding kelas yang menggunakan model konvensional. Hal ini menunjukan bahwa siswa dalam melakukan praktek diperlukan keseriusan dalam belajar sehingga mereka baik dalam pemahaman teori dan prakteknya.

\section{Kesimpulan dan Saran}

Hasil penelitian diperoleh dengan besar rekapitulasi peningkatan skor rata-rata gain ternormalisasi hasil belajar ranah kognitif untuk kelas eksperimen dengan kategori sedang. Sama halnya dengan besar rekapitulasi peningkatan skor rata-rata gain ternormalisasi hasil belajar kognitif untuk kelas kontrol dengan kategori sedang, walaupun kedua kelas berada pada kategori yang sama, namun kedua kelas tersebut memiliki $n$-gain yang berbeda dan lebih unggul kelas eksperimen dibanding kelas kontrol. Nilai signifikansi untuk postest yang menggunakan uji-t dalam penelitian ini menunjukan bahwa nilai-t lebih besar dibanding t-tabel dengan kesimpulan bahwa terdapat perbedaan hasil belajar geografi antara siswa yang diberi model Brain Based Learning dengan siswa yang diberi model konvensional pada mata pelajaran geografi kelas XI.

Hasil belajar ranah afektif yaitu A1/serius terhadap pembelajaran untuk kategori 1 siswa yang hanya mendengarkan dan memperhatikan saja dengan nilai rata-rata kelas eksperimen yaitu pada kategori rendah sekali. Kategori 2 yaitu siswa yang mendengarkan, memperhatikan dan mencatat tetapi tidak bertanya mengenai materi pelajaran dengan nilai rata-rata kelas eksperimen yaitu pada kategori sedang. Kategori 3 yaitu siswa yang mendengarkan, memperhatikan, mencatat dan bertanya mengenai materi pelajaran dengan nilai rata-rata kelas eksperimen yaitu pada kategori rendah. Hasil belajar ranah psikomotor yaitu P2/melakukan penyelidikan untuk kategori 1 siswa yang siswa yang melakukan penyelidikan tetapi tidak sesuai prosedur dengan nilai ratarata kelas eksperimen yaitu pada kategori rendah sekali. Kategori 2 yaitu siswa yang melakukan penyelidikan dengan benar tetapi terdapat tahapan yang tidak sesuai dengan prosedur dengan nilai rata-rata eksperimen yaitu pada kategori sedang. Kategori 3 yaitu 
siswa melakukan penyelidikan sesuai dengan prosedur dengan nilai rata-rata kelas eksperimen yaitu pada kategori sedang.

Beberapa kendala yang ditemukan saat penelitian yaitu perlu diperhatikan faktor-faktor lain yang menentukan keberhasilan suatu penerapan model pembelajaran ini. Faktor tersebut antara lain faktor lingkungan, visual, lingkungan psikologis, nutrisi siswa dan disfungsi otak. Pengaturan waktu dalam pembelajaran yang perlu diperhatikan, ketika melakukan penelitian kendala ini sering terjadi saat berlangsungnya pembelajaran, terkadang untuk setiap tahapan terasa kekurangan waktu dan kelebihan waktu. Interaksi antara siswa dan guru diperhatikan, dengan karakteristik model brain based learning ini, diharapkan guru harus lebih peka terhadap kebutuhan siswa, dengan adanya senam otak, visualisasi berupa video, mind maping, kuis, teka teki, analogi materi dengan kejadian yang ada serta reward membantu siswa lebih memudahkan memahami materi dalam proses pembelajaran. Penggunaan musik ketika proses pembelajaran perlu diperhatikan, terkadang ada beberapa siswa yang tidak menyukai musik ketika proses pembelajaran berlangsung.

Saran untuk perbaikan peneliti selanjutnya yaitu, apabila menggunakan model ini dalam pembelajaran, perlu diperhatikan pengelolaan waktu yang baik sehingga tidak terjadi kendala seperti kekurangan waktu atau kelebihan waktu. Pembelajaran ini banyak dipengaruhi oleh banyak faktor. Usahakan peneliti memenuhi faktor-faktor tersebut karena akan berpengaruh terhadap hasil penelitian. Saat menggunakan musik alangkah lebih baik untuk melakukan kesepakatan dengan siswa apakah dalam proses pembelajaran perlu menggunakan musik atau tidak menggunakan musik, karena penggunaan musik merupakan opsional sehingga bisa menggunakan dan bisa tidak menggunakan Apabila menggunakan musik perlu diperhatikan waktu dan tahapan yang tepat. Pergunakan musik sesuai dengan kebutuhan, dan gunakan musik yang berbeda pada setiap pertemuan sehingga siswa tidak merasa bosan dan terganggu dengan musik tersebut.

\section{Daftar Pustaka}

Sumber Tercetak:

Ali, Muhammad, (1992). Strategi Penelitian Pendidikan, Bandung, Angkasa.

Anderson, L.W., dan Krathwohl, D.R. (2001). A Taxonomy for Learning, Teaching, and Assesing;A revision of Bloom's Taxonomy of Education Objectives. New York: Addison Wesley Lonman Inc.

Arifin, Zainal (2009). Evaluasi Pembelajaran. Bandung: PT. Remaja Rosdakarya.

Arifin, Zainal (2011). Penelitian Pendidikan Model dan Paradigma Baru. Bandung: PT. Remaja Rosdakarya

Arikunto, Suharsimi (2002). Prosedur Penelitian Suatu pendekatan Praktek. Jakarta: Rineka cipta

Bloom, Benjamin S., etc. (1956). Taxonomy of Educational Objectives : The Classification of Educational Goals, Handbook I Cognitive Domain. New York : Longmans, Green and Co.

Dennison, P. E., and Dennison, G.E. (2002). BrainGym. Jakarta: PT. Grasindo.

Harmanto, Gatot. (2008). Geografi Bilingual untuk SMA/MA kelas X Semester 1 dan 2. Bandung: Yrama Widya

Jensen, Eric (2008). Brain Based Learning-Pembelajaran Berbasis Kemampuan Otak (edisi revisi). Yogyakarta: Pustaka Belajar 
Kamdi, Waras. (2009). Project-Based Learning: Pendekatan Pembelajaran Inovatif. Malakah Pelatihan Penyusunan Bahan Ajar Guru SMP dan SMA Kota Tarakan. Malang : Universitas Malang

Masykur, Moch dan Abdul Halim Fathani. (2008). Mathematical Intelligence : Cara Cerdas Melatih Otak dan Menanggulangi Kesulitan Belajar. Jogjakarta. Ar-Ruzz Media

Muhibbin Syah, (2008). Psikologi Pendidikan, Bandung: PT Remaja Rosdakarya.

Mulyati. (2005). Psikologi Belajar. Yogyakarta: CV Andi Offset

Noback, C.R. (1995) Otak : Anatomi gros, Aliran darah dan Selaput Otak dalam Anatomi Susunan Saraf Manusia. Edisi 2. Jakarta. EGC

Purwanto. (2011). Evaluasi Hasil Belajar, Dasar-dasar Evaluasi Pembelajaran. Yogyakarta: Pustaka Pelajar

Rahmat, J. (2005). Belajar Cerdas: Belajar Berbasis Otak. Bandung: Mizan Leraning Center (MLC)

Rusman (2010). Model-model Pembelajaran Mengembangkan Profesionalisme Guru. Jakarta: Raja Grafindo Persada

Riduwan (2009). Model dan Teknik Menyusun Proposal Penelitian. Bandung: Alfabeta

Sanjaya. Wina (2007). Penelitian dan Penilaian Pendidikan. Bandung: PT. Remaja Rosdakarya

Sugiyono (2010). Model Penelitian Kuantitatif Kualitatif $R \& D$. Bandung: Alfabeta

Sumaatmadja, Nursid. (1981). Studi Geografi Suatu Pendekatan dan Analisa Keruangan. Bandung : Alumni.

Yusuf. (2002). Psikologi Perkembangan Anak dan Remaja. Bandung: PT Remaja Rosdakarya.

Wibisono, Aditya.(2015) Efektifitas Penerapan Model Brain Based Learning terhadap Hasil Belajar Siswa. Skripsi: Universitas Pendidikan Indonesia.

Sumber online:

Arifuddin. (2009). Hubungan antara Motivasi dengan Prestasi Belajar Siswa pada Mata Pelajaran Geografi di Kelas XI IPS S MA Negeri 2 Singaraja. Diakses tanggal 29 Maret 2015 tersedia: http://lambitu.wordpress.com/2009/10/28/hubungan-antara-motivasi-denganprestasi-belajar-siswa-pada-mata-pelajaran-geografi-di-kelas-xi-ips-sma-negeri-2singaraja/.pdf

Mulyana, Aina. (2012). Pengertian Hasil Belajar dan Faktor-Faktor Yang Mempengaruhinya. Diakses tanggal 18 Maret 2015. Tersedia: http://ainamulyana.blogspot.com/2012/01/pengertian-hasil-belajar-dan-faktor.html 